\title{
Understanding the growth of the bio-struvite production Brevibacterium antiquum in sludge liquors
}

\author{
Francisco Simoes $^{\mathrm{a}}$, Peter Vale ${ }^{\mathrm{b}}$, Tom Stephenson ${ }^{\mathrm{a}}$, Ana Soares ${ }^{\mathrm{a} 1}$ \\ ${ }^{a}$ Cranfield Water Science Institute, Cranfield University, Cranfield, MK43 0AL, UK \\ ${ }^{\mathrm{b}}$ Technology and Development, Severn Trent Water Ltd., Avon House, St. Martins Road, \\ Coventry, CV3 6PR, UK
}

\begin{abstract}
Biological struvite (bio-struvite) production through biomineralisation has been suggested as an alternative to chemically derived struvite production to recover phosphorus from wastewater streams. In this study, statistical experimental design techniques were used to find the optimal growth rate $(\mu)$ of Brevibacterium antiquum in sludge liquors. Acetate, oleic acid, $\mathrm{NaCl}, \mathrm{NH}_{4}-\mathrm{N}$, and $\mathrm{Ca}^{2+}$ were shown to affect the growth rate of $B$. antiquum. The growth rate reached $3.441 / \mathrm{d}$ when the bacteria was supplemented with $3.0 \% \mathrm{w} / \mathrm{v} \mathrm{NaCl}$ and $1124 \mathrm{mg}$ $\mathrm{COD} / \mathrm{L}$ as acetate. However $\mathrm{NaCl}$ was found to hinder the biomineralization of bio-struvite. A two stage experiment was set-up in such away that the first stage promoted growth (using sludge liquors with $\mathrm{NaCl}$ and acetate) followed by a second stage to produce bio-struvite with only acetate. Bio-struvite production was confirmed with X-ray spectroscopy and crystal morphology (prismatic, tabular, and twinned-crystal habit) through electron microscope analysis. The bio-struvite production was estimated by measuring phosphate content of the recovered precipitates, reaching $9.6 \mathrm{mg} \mathrm{P/L}$ as bio-struvite. Overall theses results demonstrated the optimal conditions required to achieve high growth rates as well as bio-

\footnotetext{
${ }^{1}$ Corresponding author at Cranfield Water Science Institute, Cranfield University, Cranfield, MK43 0AL, UK, UK. Tel.: +44 (0) 1234 758121. E-mail address: a.soares@cranfield.ac.uk (A. Soares).
} 
struvite production with $B$. antiquum. The results obtained in this study could be used to develop a process to grow $B$. antiquum in wastewater streams in mixed cultures and recover phosphorus rich products such as struvite.

\section{Keywords}

Biomineralisation; centrate; phosphorus recovery; wastewater; mixed-culture;

\section{Introduction}

Phosphorus $(\mathrm{P})$ is a mineral nutrient of limited availability but crucial to ensure worldwide food security [1]. Wastewater treatment plants (WWTP) receive and treat streams with significant $\mathrm{P}$ concentrations $(2-15 \mathrm{mg} \mathrm{P} / \mathrm{L}$ in wastewater and up to $200 \mathrm{mg} \mathrm{P} / \mathrm{L}$ in sludge dewatering liquors) where P recovery can be instigated [2]. Phosphorus recovery from sludge dewatering liquors as struvite has been shown feasible at commercial scale, however this process is not always viable, requiring streams with high phosphate $\left(\mathrm{PO}_{4}-\mathrm{P}\right)$ concentrations $>70 \mathrm{mg} \mathrm{PO}_{4}-\mathrm{P} / \mathrm{L}[3]$.

Biological struvite (bio-struvite) production through biomineralisation has been suggested as an alternative to chemically derived struvite production, currently getting significant interest from the scientific community around the world [4-7]. Biomineralisation is a common process occurring in the natural environment in which living organisms are able to form minerals (e.g.: calcium carbonate; magnetite, struvite; magnesium phosphate; calcium phosphate etc) [8]. Phosphorus recovery from wastewater and sludge liquors using biomineralising bacteria has been shown possible but the process is still poorly understood and it has not yet been optimized [6]. Nevertheless, some promising result have shown that bio-struvite productivity by Brevibacterium antiquum can reach $200 \mathrm{mg}$ in $1 \mathrm{~L}$ of sludge dewatering liquors with an initial concentration of $44.5 \pm 2 \mathrm{mg} \mathrm{PO}-\mathrm{P} / \mathrm{L}$ [9]. B. antiquum was isolated by Gavrish et al. [10] from a permafrost sample and was characterised as aerobic heterotroph able to grow at temperatures as low as $7^{\circ} \mathrm{C}$ (but not at $37^{\circ} \mathrm{C}$ ), in high salinity environments (up to $18 \% \mathrm{NaCl}$ ) and to be able hydrolyse urea and gelatin. Furthermore B. antiquum was not able to use starch as carbon source and it was not able to reduce nitrate or produce $\mathrm{H}_{2} \mathrm{~S}$ [10]. Following from the study of Gavrish et al. [10], there is still a need to 
understand and characterise the growth requirements in of $B$. antiquum in complex and substrate limited media such as sludge dewatering liquors. This information is crucial to develop a process with conditions where the growth of $B$. antiquum can be favoured in relation to indigenous organisms in sludge dewatering liquors, thus enabling the production of bio-struvite in open mixed-culture reactors. The use of pure culture systems is perceived as unpractical and too costly to be implemented in wastewater treatment plants.

Hence the optimal growth conditions of B. antiquum in sludge dewatering liquors needs to be investigated for the impact of factors such as electron donor and electron acceptor, nutrient requirements, impact of $\mathrm{pH}$, salinity etc., [11]. Also factors potentially important for biostruvite formation such as the concentration and molar ratio of the struvite-ion species (i.e.: magnesium $\left(\mathrm{Mg}^{2+}\right)$, ammonium $\left(\mathrm{NH}_{4}-\mathrm{N}\right)$, and $\left.\mathrm{PO}_{4}-\mathrm{P}\right)$; the $\mathrm{pH}$, salinity, temperature, presence of foreign ions as calcium, should be considered [3].

Taking in consideration the factors described above, as well as the practicality of changing the sludge liquors characteristics and environmental conditions in an open reactor in a WWTP, the following parameters were selected for further investigation in this study: $\mathrm{Mg}^{2+}, \mathrm{NH}_{4}-\mathrm{N}$, $\mathrm{PO}_{4}-\mathrm{P}, \mathrm{Ca}^{2+}, \mathrm{NaCl}$ and two carbon sources, a readily available source - acetate and a more complex form of carbon - oleic acid. Statistical experimental design techniques are frequently used to streamline experimental complexity and assess the effect and interaction of several factors on microbial viability and growth $[12,13]$. The experimental sequence starts with a screening phase to identify the factors that have a significant impact on the response to be being optimized. The Plackett-Burman (PB) methodology is particularly efficient for the screening phase as it allows the test of $\mathrm{N}-1$ factors with $\mathrm{N}$ experiments (where $\mathrm{N}$ is the number of experiments and is a multiple of 4) [14]. The PB methodology produces a first order approximation of the design space that estimates the response variable, such as growth rate $(\mu)$, as a function of the factors with significant impact [13]. The next stage is to optimise the response variable until a maximum is found using the path of steepest ascent method (PSA). Further testing is then required to refine the model of the response variable as a function of the factors investigated. This step is typically completed with an experimental 
design that minimizes the number of tests whilst providing an indication of the interactions factors. This is frequently accomplished with a central composite experimental design [15].

The application of statistical experimental design techniques has been demonstrated in literature as Cheng et al. [13] identified the variables and optimal conditions to increase the activity of lipase from Bacillus subtilis by 5 fold. In another study, the optimization of phenol degradation by Candida tropicalis in synthetic phenol-rich effluent was investigated, resulting in $99 \%$ phenol degradation [14].

In this study, statistical experimental design techniques were used to investigate the optimal growth rate $(\mu)$ of $B$. antiquum in sludge dewatering liquors for factors such as $\mathrm{Mg}^{2+}, \mathrm{NH}_{4}-\mathrm{N}$, $\mathrm{PO}_{4}-\mathrm{P}, \mathrm{Ca}^{2+}, \mathrm{NaCl}$ and two carbon sources. Tests were also completed to understand the impact of the factors responsible for optimal growth conditions of B. antiquum on bio-struvite production.

\section{Materials and Methods}

\section{Microorganism and cultivation in sludge dewatering liquors}

Brevibacterium antiquum (DSM 21545) was purchased from the German Resource Centre for Biological Material (Braunschweig, Germany). Starter cultures were grown in B41 synthetic media ( $4 \mathrm{~g} / \mathrm{L}$ of yeast extract, $2 \mathrm{~g} / \mathrm{L}$ of magnesium sulphate heptahydrate, and $2 \mathrm{~g} / \mathrm{L}$ of dipotassium hydrogen phosphate), incubated in conical flasks, at room temperature $\left(20-22^{\circ} \mathrm{C}\right)$, under agitation at $150 \mathrm{rpm}$ (Stuart SSL1, Fisher Scientific, Loughborough, UK) for 4 days [6]. Inoculation of sludge dewatering liquors was done with B. antiquum cells centrifuged (Sanyo MSE Falcon 6/300 centrifuge, 2400g, $5 \mathrm{~min}$ ) from starter cultures and resuspended in the same volume of autoclaved $0.9 \% \mathrm{NaCl}$ aqueous solution, in order to avoid the addition of $\mathrm{PO}_{4}, \mathrm{NH}_{4}-\mathrm{N}$ and $\mathrm{Mg}^{2+}$ present in the B41 media to the sludge dewatering liquors [6]. In all the experiments, the sludge dewatering liquors were sterilized by autoclaving at $121^{\circ} \mathrm{C}$ for 20 min after controlling the $\mathrm{pH}$ to obtain a post-autoclave $\mathrm{pH}$ of 7.8 . 


\section{Sludge dewatering liquors}

Sludge dewatering liquors were collected from a full-scale WWTP with 500,000 population equivalent, with biological nutrient removal (BNR) as secondary treatment. Primary and secondary sludge produced onsite and import sludge, from nearby WWTP (40\% v/v), were stabilized in standard operated anaerobic digesters. After digestion the sludge was stored in a holding tank, from 10 to 27 days, before dewatering. A horizontal centrifuge decanter was used to dewater the sludge from typical $7 \%$ solids to $22 \%$ solids content. Cationic polymer, antiscaling and antifoaming agents were used to aid the centrifugation process. Samples of sludge dewatering liquors were frequently collected directly from the horizontal centrifuge decanter and stored at $4^{\circ} \mathrm{C}$ before being used in the experiments.

\section{Optimisation of $B$. antiquum growth using a statistical experimental design method}

\section{Screening of factors}

A Plackett-Burman (PB) experimental design was used to screen 7 factors: $\mathrm{Mg}^{2+}, \mathrm{NH}_{4}-\mathrm{N}$, $\mathrm{PO}_{4}-\mathrm{P}, \mathrm{Ca}^{2+}, \mathrm{NaCl}$ acetate, and oleic acid at 2 different concentrations (Table 1). The concentration of $\mathrm{NH}_{4}-\mathrm{N}$ in the sludge dewatering liquors was decreased by applying $8 \mathrm{~g} / \mathrm{L}$ of Mesolite (NanoChem Pty Ltd, Sydney, Australia) to the sludge dewatering liquors and allowing to equilibrate under agitation with a magnetic stirrer for 18 hours. Mesolite is an ion exchange zeolite media that has been shown to be highly selective for $\mathrm{NH}_{4}-\mathrm{N}$ when applied to sludge dewatering liquors [16].

Twelve tests were prepared in $1 \mathrm{~L}$ conical borosilicate glass flask containing $300 \mathrm{~mL}$ of sludge dewatering liquors inoculated with B. antiquum at $1 \% \mathrm{v} / \mathrm{v}$ ratio, stoppered with foam polystyrene plugs and then incubated for 8 days (Table 2). Samples were taken daily to measure the growth rate of $B$. antiquum using flow cytometry. At the end of the incubation period, bio-struvite produced was filtered identified and quantified. 


\section{Optimisation of the screened growth factors}

In order to optimise the factors that significantly influenced the growth of B. antiquum, the path of steepest ascent (PSA) method was applied, following from the first order model obtained in PB experiment. Eleven tests were prepared with different levels of acetate and $\mathrm{NaCl}$. For each step tested, the $\mathrm{NaCl}$ and acetate concentration of the sludge dewatering liquors were increased with $1.5 \% \mathrm{w} / \mathrm{v} \mathrm{NaCl}$ and acetate in chemical oxygen demand (COD) equivalent to $562 \mathrm{mg} \mathrm{COD} / \mathrm{L}$. Two control tests were prepared with sludge dewatering liquors, without any addition of acetate or $\mathrm{NaCl}$. The tests were inoculated with B. antiquum at $1 \% \mathrm{v} / \mathrm{v}$ ratio, stoppered with foam polystyrene plugs and then incubated for 7 days. Samples were taken daily to measure the growth rate of B. antiquum using flow cytometry. At the end of the incubation period, bio-struvite produced was filtered identified and quantified.

In order to assess for possible interactions between $\mathrm{NaCl}$ and acetate on the $B$. antiquum growth, the concentrations that resulted in higher growth rate in the PSA experiment $3.0 \%$ w/v NaCl and $1124 \mathrm{mg} \mathrm{COD/L}$ as acetate) were used as the central point for a circumscribed central composite design (CCD) experiment. In order to estimate the variation of the growth rate, 8 other tests were prepared with $\mathrm{NaCl}$ and acetate amounts equally placed around the central point in design space: $3 \pm 1.5 \%$ of $\mathrm{NaCl}$ and $1124 \pm 562 \mathrm{mg} \mathrm{COD} / \mathrm{L}$ as acetate. Two control tests were prepared with sludge dewatering liquors, without any addition of acetate or $\mathrm{NaCl}$.

All the tests were inoculated with $B$. antiquum at $1 \% \mathrm{v} / \mathrm{v}$ ratio, stoppered with foam polystyrene plugs and then incubated for 7 days. Samples were taken daily to measure the growth rate of $B$. antiquum using flow cytometry. At the end of the incubation period, biostruvite produced was filtered identified and quantified.

\section{Bio-struvite formation under optimal growth conditions}

\section{One-stage incubation experiments}

Experiments were completed to understand the impact of $\mathrm{NaCl}$ and acetate on the bio-struvite production. Four $125 \mathrm{~mL}$ bottles with $50 \mathrm{~mL}$ of dewatering liquors were supplemented with $562,1124,1686$, and $2248 \mathrm{mg} \mathrm{COD} / \mathrm{L}$ as acetate, four other bottles were supplemented with 
$1.5,3.0,4.5$, and $6.0 \%$ of $\mathrm{NaCl}$. Control tests were also prepared with without any addition of acetate or $\mathrm{NaCl}$, or addition of $\mathrm{B}$. antiquum to assess spontaneous struvite precipitation and microbial contamination, respectively. All the inoculated tests were added B. antiquum at $1 \% \mathrm{v} / \mathrm{v}$ ratio and all test were incubated for 6 days. Samples were taken daily to measure the growth rate of $B$. antiquum using flow cytometry. In this experiment the bio-struvite production was quantified by measuring the $\mathrm{PO}_{4}-\mathrm{P}$ after isolation of the bio-struvite with differential density centrifugation. This method was considered more accurate as it allowed the quantification of bio-struvite crystals $<10 \mu \mathrm{m}$.

\section{Two-stage incubation experiments}

In the one-stage incubation experiments the bio-struvite production was very low. To understand these results, a two-stage incubation experiment was completed: the first stage aimed at promoting growth of $B$. antiquum by adding acetate and $\mathrm{NaCl}$ to the sludge dewatering liquors. The second stage aimed at bio-struvite production with no addition of $\mathrm{NaCl}$.

In the first stage, acetate was added at 0, 281, 562, 1124, and $1686 \mathrm{mg} \mathrm{COD/L} \mathrm{(as} \mathrm{acetate)} \mathrm{and}$ $\mathrm{NaCl}$ was added at $3.0 \% \mathrm{w} / \mathrm{v}$. After 3 days of incubation the liquors were centrifuged (Sanyo MSE Falcon 6/300 centrifuge, 2400g, $10 \mathrm{~min}$ ), the supernatant sludge dewatering liquors were collected, and replaced with sludge dewatering liquors with acetate (equivalent to 281 mg $\mathrm{COD} / \mathrm{L}$ ), without $\mathrm{NaCl}$ addition. Control tests were also prepared without acetate or $\mathrm{NaCl}$, or addition of B. antiquum to assess spontaneous struvite precipitation and microbial contamination, respectively. Samples were taken daily to measure the growth rate of $B$. antiquum using flow cytometry. At the end of the incubation period, bio-struvite produced was filtered for identification using electron microscopy. The bio-struvite production was quantified by measuring the $\mathrm{PO}_{4}-\mathrm{P}$ after isolation of the bio-struvite with differential density centrifugation.

\section{Sample analysis and analytical methods}

Total phosphorus (TP), and COD were measured using Merck cell test kit according to the manufacturer instructions. Magnesium was analysed using an atomic absorption 
spectrophotometer (Analyst 800, Perkin Elmer Ltd, Beaconsfield, UK) equipped with an air/acetylene burner system. The $\mathrm{pH}$ was measured with a Fisherbrand hydrous $300 \mathrm{pH}$ meter (Fisher Scientific, Loughborough, UK) immediately after sampling. Ammonia and $\mathrm{PO}_{4}$ were measured using a Smartchem 200 discrete analyser according to the manufacturer instruction (Labmedics, Abingdon, UK).

The growth rates of the selected bacteria were calculated from intact cell counts measured daily using flow cytometry. Intact cells counts were measured using a SYBR Green I and propidium iodide dye mixture with an incubation period of 11 min at $37^{\circ} \mathrm{C}$ and following the procedure detailed in Lipphaus et al. [17].

In order to identify and quantify the bio-struvite produced, the sludge dewatering liquors samples were vacuum-filtered through a previously dried ( 2 hours, $37^{\circ} \mathrm{C}$ ), and weighted, 10 $\mu \mathrm{m}$ aperture nylon mesh sheet (Plastok Associates, Birkenhead, UK). The crystals were washed with a small quantity of washing water (deionized water adjusted to $\mathrm{pH} 10$ with $1 \mathrm{M}$ $\mathrm{NaOH}$ ) and allowed to dry at $37^{\circ} \mathrm{C}$ for 2 hours before being weighed. The crystals were identified using high resolution scanning electron microscopy (SEM) with energy dispersive X-ray spectroscopy (EDX) (scanning electron microscope XL 30 SFEG, Phillips, The Netherlands).

In order to account for bio-struvite crystals smaller than $10 \mu \mathrm{m}$, a differential density centrifugation method was applied [18]. This method allows the separation of liquids (and particles) according to their density. The density of the sludge dewatering liquors was assumed similar to water $(1 \mathrm{~kg} / \mathrm{L})$; bacterial cells and proteins have relative density $1.1 \mathrm{~kg} / \mathrm{L}$ and 1.3, respectively [19], and struvite crystals have relative density of $1.7 \mathrm{~kg} / \mathrm{L} \mathrm{[3].} \mathrm{A} \mathrm{sucrose}$ solution $(2000 \mathrm{~g} / \mathrm{L}$; density of $1.3 \mathrm{~kg} / \mathrm{L})$ was layered at the bottom on a centrifuge tube $(5 \mathrm{~mL})$ and the sludge dewatering liquors were added on top. After centrifugation for 10 min (Sanyo MSE Falcon 6/300 centrifuge, 2400g), the supernatant, made up of sludge dewatering liquors and bacterial cells, was discarded and removed with $3-4 \mathrm{~mL}$ of the sucrose layer. The remainder was dissolved with $10 \mathrm{~mL}$ of $0.05 \mathrm{M} \mathrm{HCl}$ and the phosphate content quantified and used to estimate the amount of bio-struvite produced. 


\section{Results and Discussion}

The sludge dewatering liquors used in this study were analysed for typical wastewater quality parameters across the different samples collected (Table 3). The COD concentrations were rather stable at around $455 \pm 12 \mathrm{mg} / \mathrm{L}$. The measured nutrient concentrations were $882 \pm 31 \mathrm{mg} \mathrm{NH}_{4}-\mathrm{N} / \mathrm{L}, 33 \pm 5 \mathrm{mg} \mathrm{PO}_{4}-\mathrm{P} / \mathrm{L}$ and $55 \pm 9 \mathrm{mg} \mathrm{Mg}^{2+} / \mathrm{L}$ with a $\mathrm{pH}$ of $7.9 \pm 0.1$. Existing literature on sludge dewatering liquors originated from biological nutrient removal sites, indicated lower $\mathrm{NH}_{4}-\mathrm{N}$ concentrations at $551-610 \mathrm{mg} \mathrm{NH}-\mathrm{N} / \mathrm{L}_{\text {and }} \mathrm{Mg}^{2+}$ at $11.2-$

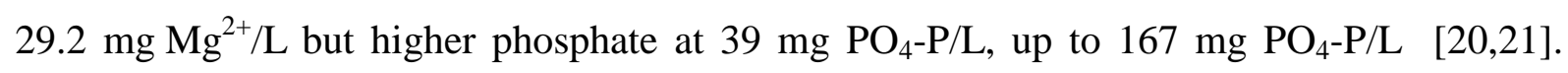
Hence the sludge dewatering liquors used in this study had lower $\mathrm{PO}_{4}-\mathrm{P}$ concentrations than typically found in sludge dewatering liquors originated from biological nutrient removal sites.

The PB experiment was carried out to screen the impact of selected factors: $\mathrm{Mg}^{2+}, \mathrm{NH}_{4}-\mathrm{N}$, $\mathrm{PO}_{4}-\mathrm{P}, \mathrm{Ca}^{2+}, \mathrm{NaCl}$ and two carbon sources (a readily available source - acetate and a more complex form of carbon - oleic acid), on the growth rate of B. antiquum on sludge dewatering liquors to obtain a first approximation linear model. The growth rates observed ranged from 0.50 to $3.441 / \mathrm{d}$ with the control test (Test 1 ) having a growth rate of $0.931 / \mathrm{d}$ (Table 4). The significance of each factor was assessed by a multi variance analysis of the fitted model of growth rate response (Table 5). The fitted model was found to be have a significant correlation of $98 \%$ ( $\mathrm{r}^{2}$ - adjusted for the degrees of freedom) with a mean absolute error of 0.06 , and a global $p$-value of $0.03 \%$. These values indicate a very low probability that the results obtained could have occurred by random chance, and indicate that the fitted model explains $>98 \%$ of the variability observed in the growth rate.

The highest growth rate was obtained when high levels of $\mathrm{Mg}^{2+}, \mathrm{NH}_{4}-\mathrm{N}, \mathrm{PO}_{4}-\mathrm{P}, \mathrm{NaCl}$, acetate and oleic acid and low levels of $\mathrm{Ca}^{2+}$, were present in the liquors. Both acetate and oleic acid showed a significant and comparable impact on the growth rate of $B$. antiquum with acetate having a better response $(\mu=1.921 / \mathrm{d})$ than oleic acid $(\mu=1.771 / \mathrm{d})$. The addition of a carbon source in WWTPs, is a common practice in denitrification and enhanced biological phosphate removal processes, in order to stimulate the proliferation of selected bacteria such as denitrifiers and phosphorus accumulating organisms [22,23]. A similar approach might also benefit the growth of $B$. antiquum. The addition of $\mathrm{NaCl}$ at a rate of $6 \% \mathrm{w} / \mathrm{v}$ showed a 
positive effect on the growth rate $(\mu=1.621 / \mathrm{d})$ and can possibly be used as a selective pressure to create a process environment where B. antiquum can outcompete the indigenous bacteria, and thus remain in stable concentrations to allow using sludge dewatering liquors without the need for sterilization.

The first order model, obtained in the screening experiment functioned as an initial approximation of the growth rate of B. antiquum as a function of the factors tested. To further optimize the growth response, the model space was additionally explored following the PSA method. Hence, increased amounts of acetate (+562 mg COD/L) and of $\mathrm{NaCl}(+1.5 \% \mathrm{w} / \mathrm{v})$, were tested. The model was not further optimized in terms of $\mathrm{Ca}^{2+}$ or $\mathrm{NH}_{4}$ concentration given that controlling these factors seems impractical in a WWTP.

The results for the PSA experiment showed that the conditions that resulted in the highest growth rate, $3.321 / \mathrm{d}$, were found with $3.0 \% \mathrm{w} / \mathrm{v} \mathrm{NaCl}$ and $1124 \mathrm{mg} \mathrm{COD} / \mathrm{L}$ as acetate (Table 6). Test 1 and Test 3 followed with the $2^{\text {nd }}$ and $3^{\text {rd }}$ highest growth rates of 2.87 and $2.751 / \mathrm{d}$, respectively. The remaining observed growth rates were also well within the range observed in the screening experiment of 0.50 to $3.441 / \mathrm{d}$. This indicated that the factors required for maximum growth rate were close to the conditions found on Test $2(3.0 \% \mathrm{w} / \mathrm{v} \mathrm{NaCl}$ and 1124 $\mathrm{mg} \mathrm{COD} / \mathrm{L}$ as acetate). A CCD experiment was used to assess the main effects and interactions of acetate and $\mathrm{NaCl}$ around a central point with $3.0 \% \mathrm{w} / \mathrm{v} \mathrm{NaCl}$ and $1124 \mathrm{mg}$ $\mathrm{COD} / \mathrm{L}$ as acetate. The growth rates observed were between $2.43-3.201 / \mathrm{d}$ and statistically similar (mean at the central point was $\mu=2.75 \pm 0.081 / \mathrm{d}$ ). These results demonstrate that the maximum growth rate measured could be obtained at a range of conditions tested, indicating that B. antiquum resilience and flexibility. This can be seen as an important advantage allowing for flexibility on the design of a bio-struvite production process as high growth rates can be obtained for $\mathrm{NaCl}$ and acetate concentrations within $3 \pm 1.5 \%$ and $1124 \pm 562$ $\mathrm{mg}$ COD/L as acetate, respectively.

The B. antiquum growth rate of $3.441 / \mathrm{d}$ was 60 fold higher than previously reported at 0.05 1/d [6]. Nevertheless, the lower growth rate was estimated using turbidity measurements and no addition of extra carbon source or $\mathrm{NaCl}$, which could potentially explain the difference in results. 
When comparing the growth rates of $B$. antiquum in this study $(\mu=3.441 / \mathrm{d}$ ) with other bacteria commonly found in WWTPs, it can be observed that B. antiquum is relatively a fast growing organism (Figure 1). Heterotrophic bacteria growing in activated sludge systems have been reported to have growth rates varying between $1-71 / \mathrm{d}$, both in domestic and several industrial wastewaters, and growth rates of up to $131 / \mathrm{d}$ in synthetic wastewater [24,25]. Heterotrophic denitrification bacteria were reported to grow rates at $3.71 / \mathrm{d}$ when using acetate as carbon source, and above $1.21 / \mathrm{d}$ with methanol [26]. Even without the use of acetate of $\mathrm{NaCl}$, B. antiquum growth rate $(\mu=0.9-1.211 / \mathrm{d})$ in sludge dewatering liquors was high relative to reported growth rates of nitrifying bacteria $(\mu=0.2-11 / \mathrm{d})$, phosphorus removal bacteria $(\mu=0.1-0.71 / \mathrm{d})[25]$ and Anammox $(\mu=0.01-0.331 / \mathrm{d})$. All these bacteria which have been successfully applied is commercially viable biological process for the treatment of wastewater and sludge dewatering liquors [27,28]. This was accomplished through application of processes and reactors with particular engineered operational conditions that work as a selective pressure limiting other competing microorganisms and allow for them to proliferate in open mixed-culture conditions [11,22].

\section{Bio-struvite production}

Visual inspection of the tests in the screening and the PSA experiments indicated that the formation of bio-struvite was occurring but was not associated with the growth rates. In the CCD experiment, the quantity of bio-struvite recovered in the inoculated tests dosed with $\mathrm{NaCl}$ and acetate $(10 \pm 6 \mathrm{mg} / \mathrm{L})$ was below the recovered in the un-inoculated control tests $(113.8 \pm 26.6 \mathrm{mg} / \mathrm{L})$. These results implied that the application of the optimization factors prevented the formation of bio-struvite.

The effects of adding separate different quantities of $\mathrm{NaCl}$ or acetate to sludge dewatering liquors were tested $(\mathrm{NaCl} /$ acetate experiment). It was observed that B. antiquum was keeping viable in all tests, with considerably higher cells counts in the tests with added acetate: 11 $28 \mathrm{x}$ more cells than in the inoculum, compared to $2 \mathrm{x}$ more in tests dosed with $\mathrm{NaCl}$ alone (Figure 2). Bio-struvite was formed in all tests supplemented with only acetate $(9.6-21.5$ $\mathrm{mg} \mathrm{P} / \mathrm{L})$ and not in the tests dosed with $\mathrm{NaCl}(0.8-1.7 \mathrm{mg} \mathrm{P} / \mathrm{L})$. When both $\mathrm{NaCl}$ and acetate were added the cell counts were comparable to the growth in the tests with acetate $(23 \mathrm{x}$ more 
than in the inoculum) but the bio-struvite production was similar to the tests with $\mathrm{NaCl}$ alone (1.2 $\mathrm{mg} \mathrm{P} / \mathrm{L})$. The results here support that was the $\mathrm{NaCl}$, and not acetate, that prevented the formation of bio-struvite in sludge dewatering liquors dosed with both $\mathrm{NaCl}$ and acetate. Organic substances as humic and citric acids have been shown to inhibit struvite formation $[29,30]$. And acetate has been reported to delay the precipitation of struvite at more than 5 $\mathrm{mM}$ (equiv. $321 \mathrm{mg} \mathrm{COD/L}$ ), but the effect was not noticeable after $25 \mathrm{~min}$ [31] a small time interval when compared to the incubation times tested here. The solubility of struvite has been found to not change significantly at $\mathrm{NaCl}$ concentrations up to $60 \mathrm{mM}$ (equiv. $0.35 \% \mathrm{w} / \mathrm{v}$ ) [32]. But the induction time for the precipitation of struvite in low $\mathrm{NH}_{4}-\mathrm{N}$ synthetic wastewater was reported to increase at sodium concentrations above $50 \mathrm{mM}$ [33]. In the current study, $\mathrm{NaCl}$ was used at 1.5 to $4.5 \%$ w/v, hence 5 fold higher than the concentration of $\mathrm{NaCl}$ that was reported to affect chemical struvite precipitation. In a study investigating the occurrence of bio-mineralization in artificial marine-salts media by halophilic bacteria, increasing salt concentrations (from 2.5 to $20 \% \mathrm{w} / \mathrm{v}$ ) was reported to lead to minerals of smaller size, and to increase the time required for precipitation from 3 to 15 days [34]. Although biomineralization mechanisms may be able to selectively change specific microenvironments independently of the macroscopic environmental conditions [8], results here showed that $\mathrm{NaCl}$ prevented bio-struvite formation in the optimized sludge dewatering liquors. Hence the growth rate of $B$. antiquum in sludge dewatering liquors can optimized by dosing acetate and $\mathrm{NaCl}$, but the second must not be present for the formation of bio-struvite to occur.

An experiment was carried to assess the production of bio-struvite in two stages. A first stage of 3 days, used to promote growth of the selected bacteria with the addition of acetate and $\mathrm{NaCl}$, was followed by a second stage of 5 days without added $\mathrm{NaCl}$. Acetate in stage 1 was tested at different initial concentrations, and the addition of extra acetate in the second stage (281 mg COD/L) was also tested. Bio-struvite was formed in all tests but for those without the addition of acetate in either of the stages (Figure 3). This confirmed that replacing sludge dewatering liquors dosed with $\mathrm{NaCl}$ and acetate by sludge dewatering liquors without $\mathrm{NaCl}$ allowed for the formation of bio-struvite. The presence of bio-struvite was confirmed with energy-dispersive X-ray spectroscopy. The spectra obtained matched the spectra expected for 
struvite crystals (Figure 4d), and the morphology of the bio-struvite crystals, observed in the electron microscope, was found to follow characteristic prismatic, tabular, and twinnedcrystal habit (Figure 4) similar to the morphologies found in other published reports on struvite [7,29-31].

In the tests where no extra acetate was added in the second stage of the two stage experiment, when the conditions in stage 1 were richer (in acetate) the bio-struvite production was higher (Figure $3 b)$. With no acetate added (Treatment A), no bio-struvite was produced $(0.0 \pm 0.6 \mathrm{mg}$ $\mathrm{P} / \mathrm{L}$ ), and with $1686 \mathrm{mg} \mathrm{COD} / \mathrm{L}$ of acetate (Treatment E), $5.7 \pm 0.4 \mathrm{mg} \mathrm{P} / \mathrm{L}$ of bio-struvite were produced. This suggests that a form of accumulation was taking place, with resources obtained in stage 1 being carried to stage 2 . This accumulation enabled B. antiquum to get to the stage 2 and produce bio-struvite.

Cell counts in stage 2 for the tests where no extra acetate was added in stage 2 of the two stage experiment (from $4.1 \times 10^{8}$ to $1.2 \times 10^{9}$ cells $/ \mathrm{mL}$, Figure $3 \mathrm{~b}$ ) were similar to the cell counts obtained in the one stage experiment (from $5.6 \times 10^{8}$ to $1.4 \times 10^{9}$ cells $/ \mathrm{mL}$, Figure $2 \mathrm{~b}$ ). However the bio-struvite produced did not match a similar trend. In the one stage experiment, more acetate (from 562 to $2248 \mathrm{mg} \mathrm{COD} / \mathrm{L}$ ) lead to less bio-struvite (from 21.5 to $9.6 \mathrm{mg}$ $\mathrm{P} / \mathrm{L}$, respectively, Figure $2 \mathrm{a})$. Whilst in the two stage experiment, with no extra acetate added in stage 2 , more acetate ( 0 to $1686 \mathrm{mg} \mathrm{COD} / \mathrm{L}$, added in stage 1 ) lead to higher bio-struvite production (from 0.0 to $5.7 \mathrm{mg} \mathrm{P} / \mathrm{L}$, respectively, Figure $3 \mathrm{~b}$ ).

Regardless of the acetate treatment in stage 1, in the tests supplemented with extra acetate ( $281 \mathrm{mg} \mathrm{COD} / \mathrm{L})$ in stage 2 of the two-stage experiment, the bio-struvite production reached a plateau of $9.0 \pm 1.4 \mathrm{mg} \mathrm{P} / \mathrm{L}$ (Figure $3 \mathrm{c}$ ), even in the tests were no acetate was added in the first stage $(9.6 \pm 0.4 \mathrm{mg} \mathrm{P} / \mathrm{L})$. The addition of acetate in the second stage contributed for bio-struvite production whilst the addition of acetate in the first stage was not essential for bio-struvite production.

It is possible that bio-struvite formation was associated with the end of the exponential growth phase. In the one stage experiment, likely more acetate translated to a longer growth phase, possibly with the accumulation of factors that can be seen as making for healthier cells. In the 
case of the two stage incubation, the exponential growth phase was interrupted to start the second stage, a change that can be expected to stress the bacteria cells. The production of secondary metabolites, as antibiotics, is associated with the end of the exponential growth phase [35]. Classical methods to increase the production of secondary metabolites involve the manipulation of the culture conditions and biological stress responses [36]. Hence the differences observed can be explained if bio-struvite is the result of secondary metabolism of B. antiquum.

\section{Conclusions}

Biological processes used in conventional wastewater treatment are typically done in open mixed-culture conditions. Ideally, a bio-struvite production process should be done in open mixed-culture conditions. To allow the stable growth of the bio-struvite bacteria $B$. antiquum in open mixed-culture conditions, a process needs to be designed in a way that allows B. antiquum to grow at a faster pace than other microorganisms present in the sludge dewatering liquors. The goal of this work was to find the optimal growth rate of B. antiquum in sludge dewatering liquors as a function of factors as $\mathrm{Mg}^{2+}, \mathrm{NH}_{4}-\mathrm{N}, \mathrm{PO}_{4}-\mathrm{P}, \mathrm{Ca}^{2+}, \mathrm{NaCl}$ and two carbon sources: acetate (ready available) and oleic acid (complex form of carbon); and to assess the impact of the factors responsible for the observed optimal growth on bio-struvite production.

Acetic acid, oleic acid, $\mathrm{NaCl}$, and $\mathrm{NH}_{4}$ were shown to have a positive impact on the growth rate of $B$. antiquum with average growth rates of $1.92,1.77,1.57,1.691 / \mathrm{d}$, respectively, in the tests with high levels. And $\mathrm{Ca}^{2+}$ was found to have a negative impact $(0.951 / \mathrm{d})$. Controlling the content of $\mathrm{NH}_{4}$ and $\mathrm{Ca}^{2+}$ in sludge dewatering liquors, in a full-scale WWTP, to favour the growth rate of $B$. antiquum, was considered unpractical but insight was gained on their impact on $B$. antiquum growth rate.

The growth rate $(\mu)$ of $B$. antiquum in sludge dewatering liquors was $0.93-1.211 / \mathrm{d}$ but this could be increased by 3 fold to $3.441 / \mathrm{d}$ when supplementing the sludge dewatering liquors with acetate $(1124 \mathrm{mg} \mathrm{COD} / \mathrm{L})$ and $\mathrm{NaCl}(3.0 \% \mathrm{w} / \mathrm{v})$. 
However $\mathrm{NaCl}$ at $3.0 \% \mathrm{w} / \mathrm{v}$ was found to hinder the biomineralization of the bio-struvite implying that the sludge dewatering liquors can be dosed with acetate and $\mathrm{NaCl}$ to improve the growth rate, but that $\mathrm{NaCl}$ must not be present to allow the formation of bio struvite. Hence, both growth and bio-struvite production could be promoted by establishing a 2 stage process. The growth stage would combine the sludge dewatering liquors with acetate and $\mathrm{NaCl}$, followed by second stage for bio-struvite production with just acetate dosing.

The fact that the growth rate of $B$. antiquum in sludge dewatering liquors can be made to reach $3.441 / \mathrm{d}$ broadens the probability of finding conditions in sludge dewatering liquors, or other wastewater streams, were B. antiquum can be used to produce bio-struvite and recover phosphorus from wastewater streams in open mixed-culture conditions.

\section{Acknowledgements}

The authors are grateful for the financial support and contribution from Severn Trent Water Ltd (Coventry, UK) and for the financial support from POPH/FSE as a Ph.D. grant (SFRH/BD/84116/2012) awarded by the Fundação para a Ciência e Tecnologia (FCT, Portugal).

\section{References}

[1] Cordell D, Smit AL, Rosemarin A, et al. Sustainable use of phosphorus. Wageningen, The Netherlands; 2009.

[2] Pratt C, Parsons SA, Soares A, et al. 2012. Biologically and chemically mediated adsorption and precipitation of phosphorus from wastewater. Curr. Opin. Biotechnol. 2012;23:890-896.

[3] Le Corre KS, Valsami-Jones E, Hobbs P, et al. Phosphorus recovery from wastewater by struvite crystallization: A Review. Crit. Rev. Environ. Sci. Technol. 2009;39:433477.

[4] Li H, Yao Q-Z, Yu S-H, et al. Bacterially mediated morphogenesis of struvite and its implication for phosphorus recovery. Am. Mineral. 2017;102:381-390.

[5] Sinha A, Singh A, Kumar S, et al. Microbial mineralization of struvite: A promising process to overcome phosphate sequestering crisis. Water Res. 2014;54:33-43.

[6] Soares A, Veesam M, Simoes F, et al. Bio-Struvite: A new route to recover phosphorus from wastewater. CLEAN - Soil, Air, Water. 2014;42:994-997.

[7] Sánchez-Román M, Rivadeneyra MA, Vasconcelos C, et al. Biomineralization of carbonate and phosphate by moderately halophilic bacteria. FEMS Microbiol. Ecol. 2007;61:273-284. 
[8] Mann S. Biomineralization: principles and concepts in bioinorganic materials chemistry. 1st ed. Mann S, editor. Oxford: Oxford University Press; 2001.

[9] Simoes F, Vale P, Stephenson T, et al. Bio-struvite production in sludge dewatering liquors: The importance of $\mathrm{pH}$ (submitted). Sci. Rep. 2017;

[10] Gavrish EY, Krauzova VI, Potekhina N V, et al. Three new species of brevibacteria-Brevibacterium antiquum sp. nov., Brevibacterium aurantiacum sp. nov. and Brevibacterium permense sp. nov. Mikrobiologiia. 2004;73:218-225.

[11] Tchobanoglous G, Burton FL, Stensel HD. Wastewater engineering: treatment and reuse. 4th, Inter ed. Tchobanoglous G, Franklin L. Burton F, Stensel HD, editors. New York: McGraw-Hill Higher Education; 2003.

[12] Sun Y, Han B, Liu W, et al. Substrate induction and statistical optimization for the production of chitosanase from Microbacterium sp. OU01. Bioresour. Technol. 2007;98:1548-1553.

[13] Cheng S-W, Wang Y-F, Liu F-F. Optimization of medium compositions using statistical experimental design to produce lipase by Bacillus subtilis. Chem. Biochem. Eng. 2011;25:377-383.

[14] Zhou J, Yu X, Ding C, et al. Optimization of phenol degradation by Candida tropicalis Z-04 using Plackett-Burman design and response surface methodology. J. Environ. Sci. 2011;23:22-30.

[15] Sarrai AE, Hanini S, Merzouk NK, et al. Using central composite experimental design to optimize the degradation of Tylosin from aqueous solution by Photo-Fenton reaction. Materials, 2016;9(6): 428.

[16] Thornton A, Pearce P, Parsons SA. Ammonium removal from digested sludge liquors using ion exchange. Water Res. 2007;41:433-439.

[17] Lipphaus P, Hammes F, Kötzsch S, et al. Microbiological tap water profile of a medium-sized building and effect of water stagnation. Environ. Technol. 2014;35:620628.

[18] Cromar NJ, Fallowfield HJ. Separation of components of the biomass from high rate algal ponds using PercollR density gradient centrifugation. J. Appl. Phycol. 1992;4:157-163.

[19] Milo R, Jorgensen P, Moran U, et al. BioNumbers The database of key numbers in molecular and cell biology. Nucleic Acids Res. 2010;38:D750-D753.

[20] Ueno Y, Fujii M. Three years experience of operating and selling recovered struvite from full-scale plant. Environ. Technol. 2001;22:1373-1381.

[21] Pastor L, Marti N, Bouzas A, et al. Sewage sludge management for phosphorus recovery as struvite in EBPR wastewater treatment plants. Bioresour. Technol. 2008;99:4817-4824.

[22] Manyumba F, Wood E, Horan N. Meeting the phosphorus consent with biological nutrient removal under UK winter conditions. Water Environ. J. 2009;23:83-90.

[23] Cherchi C, Onnis-Hayden A, El-Shawabkeh I, et al. Implication of using different carbon sources for denitrification in wastewater treatments. Water Environ. Res. 2009;81:788-799.

[24] Fall C, Hooijmans CM, Esparza-Soto M, et al. Initial-rate based method for estimating the maximum heterotrophic growth rate parameter ( $\mu$ Hmax). (2012) Biores. Technol., 2012;116:126-132. 
[25] Henze M, Gujer W, Mino T, et al. Activated sludge models ASM1, ASM2, ASM2d and ASM3. 2nd ed. IWA Task Group on Mathematical Modelling for Design and Operation of Biological Wastewater Treatment, editor. London: IWA Publishing, Scientific and Technical Report series; 2000.

[26] Mokhayeri Y, Nichols a., Murthy S, et al. Examining the influence of substrates and temperature on maximum specific growth rate of denitrifiers. Water Sci. Technol. 2006;54:155-162.

[27] Lotti T, Kleerebezem R, Abelleira-Pereira JM, et al. Faster through training: The anammox case. Water Res. 2015;81:261-268.

[28] Laureni M, Weissbrodt DG, Szivák I, et al. Activity and growth of anammox biomass on aerobically pre-treated municipal wastewater. Water Res. 2015;80:325-336.

[29] Zhou Z, Hu D, Ren W, et al. Effect of humic substances on phosphorus removal by struvite precipitation. Chemosphere. 2015;141:94-99.

[30] Zhang Q, Zhao S, Ye X, et al. Effects of organic substances on struvite crystallization and recovery. Desalin. Water Treat. 2015;1-10.

[31] Song Y, Dai Y, Hu Q, et al. Effects of three kinds of organic acids on phosphorus recovery by magnesium ammonium phosphate (MAP) crystallization from synthetic swine wastewater. Chemosphere. 2014;101:41-48.

[32] Bhuiyan MIH, Mavinic DS, Beckie RD. A solubility and thermodynamic study of struvite. Environ. Technol. 2007;28:1015-1026.

[33] Kabdaşli I, Parsons SA, Tunay O. Effect of major ions on induction time of struvite precipitation. Croat. Chem. Acta. 2006;79:243-251.

[34] Rivadeneyra MA, Delgado R, Párraga J, et al. Precipitation of minerals by 22 species of moderately halophilic bacteria in artificial marine salts media: influence of salt concentration. Folia Microbiol. (Praha). 2006;51:445-453.

[35] Ruiz B, Chávez A, Forero A, et al. Production of microbial secondary metabolites: regulation by the carbon source. Crit. Rev. Microbiol. 2010;36:146-167.

[36] Craney A, Ahmed S, Nodwell J. Towards a new science of secondary metabolism. J. Antibiot. (Tokyo). 2013;66:387-400. 


\section{Figure captions}

Figure 1 Comparison of the growth rates of $B$. antiquum in sludge dewatering liquors $(\diamond$, non-optimized; $\diamond$, optimized with $3.0 \% \mathrm{w} / \mathrm{v} \mathrm{NaCl}$ and $1124 \mathrm{mg} \mathrm{COD} / \mathrm{L}$ as acetate) with the growth rate range of values found in published literature for heterotrophic bacteria in activated sludge systems, heterotrophic denitrifying bacteria, nitrification bacteria, enhanced biological phosphorus removal (EBPR) bacteria, and Anammox bacteria [23-25,27].

Figure 2 Bio-struvite production (a) and cell counts (b) after incubating B. antiquum for 6 days in sludge dewatering liquors supplemented with 1.5, 3.0, 4.5, and 6.0\% w/v of $\mathrm{NaCl}$, and $562,1124,1686$, and $2248 \mathrm{mg} \mathrm{COD} / \mathrm{L}$ of acetate. Error bars detail the standard error of replicate tests.

Figure 3 Maximum cell counts during incubation and bio-struvite production above control tests in the two-stage incubation experiment: (a) stage 1 cell counts when incubating $B$. antiquum in sludge dewatering liquors with $3.0 \% \mathrm{w} / \mathrm{v} \mathrm{NaCl}$ and different concentrations of acetate (Treatments A:0, B:281, C:562, D:1124, and E:1686 mg COD/L); (b) stage 2 cell counts and bio-struvite production after incubating $B$. antiquum cells collected from stage 1 , in sludge dewatering liquors with no $\mathrm{NaCl}$ and no acetate; and (c) stage 2 cell counts and biostruvite production after incubating $B$. antiquum cells collected from stage 1 , in sludge dewatering liquors with no $\mathrm{NaCl}$ and with $281 \mathrm{mg} \mathrm{COD} / \mathrm{L}$ of acetate. T0 details the cell count at time zero, after inoculating B. antiquum from starter cultures. Error bars detail the standard error of replicate tests.

Figure 4 Electron scanning microscope photos of the bio-struvite collected after the two-stage experiment: stage 1 incubated $B$. antiquum for 3 days in sludge dewatering liquors with $3.0 \%$ w/v $\mathrm{NaCl}$ and 5 different concentrations of acetate, followed by stage 2 that incubated for 5 
days $B$. antiquum cells collected from stage 1 , in sludge dewatering liquors without $\mathrm{NaCl}$, and 2 levels of acetate: (a) no acetate in stage 1, followed by $281 \mathrm{mg} \mathrm{COD} / \mathrm{L}$ of acetate in stage 2; (b) $1124 \mathrm{mg} \mathrm{COD/L}$ in stage 1 , followed by $281 \mathrm{mg} \mathrm{COD} / \mathrm{L}$ of acetate in stage 2; (c) $1686 \mathrm{mg} \mathrm{COD} / \mathrm{L}$ of acetate in stage 1, followed by no acetate in stage 2. Energy-dispersive $\mathrm{X}$-ray micro-analysis spectrum of site 33 highlighted in photo (a) is characteristic struvite crystals. 


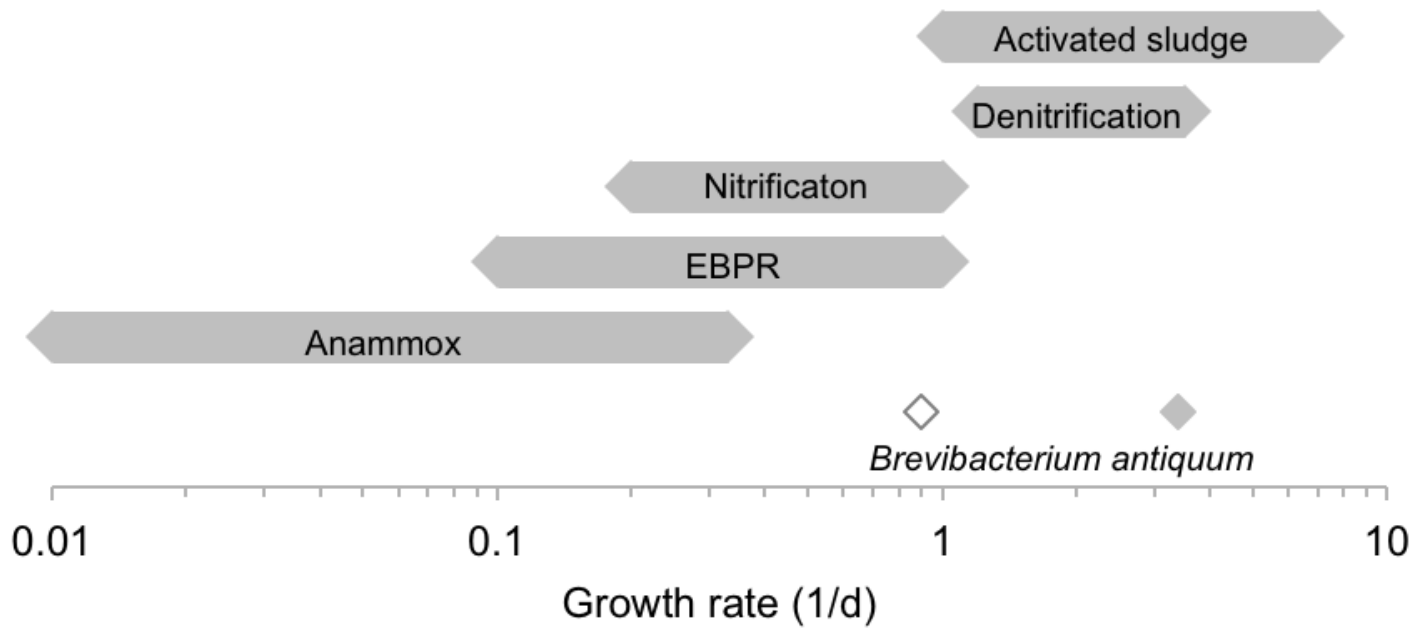

Figure 1 Comparison of the growth rates of $B$. antiquum in sludge dewatering liquors ( $\diamond$, non-optimized; $\diamond$, optimized with $3.0 \% \mathrm{w} / \mathrm{v} \mathrm{NaCl}$ and $1124 \mathrm{mg} \mathrm{COD} / \mathrm{L}$ as acetate) with the growth rate range of values found in published literature for heterotrophic bacteria in activated sludge systems, heterotrophic denitrifying bacteria, nitrification bacteria, enhanced biological phosphorus removal (EBPR) bacteria, and Anammox bacteria [23-25,27]. 
(a)

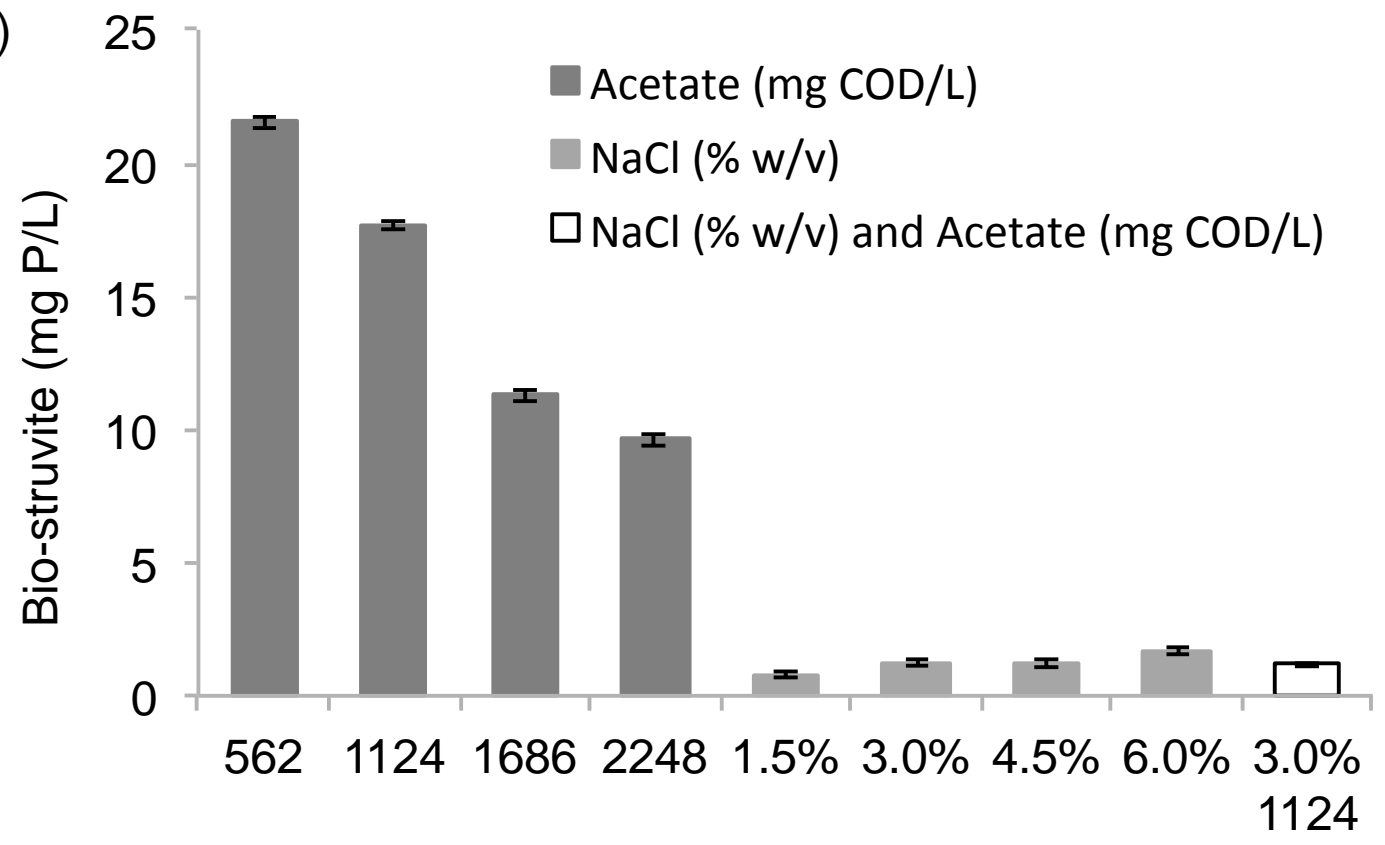

(b)

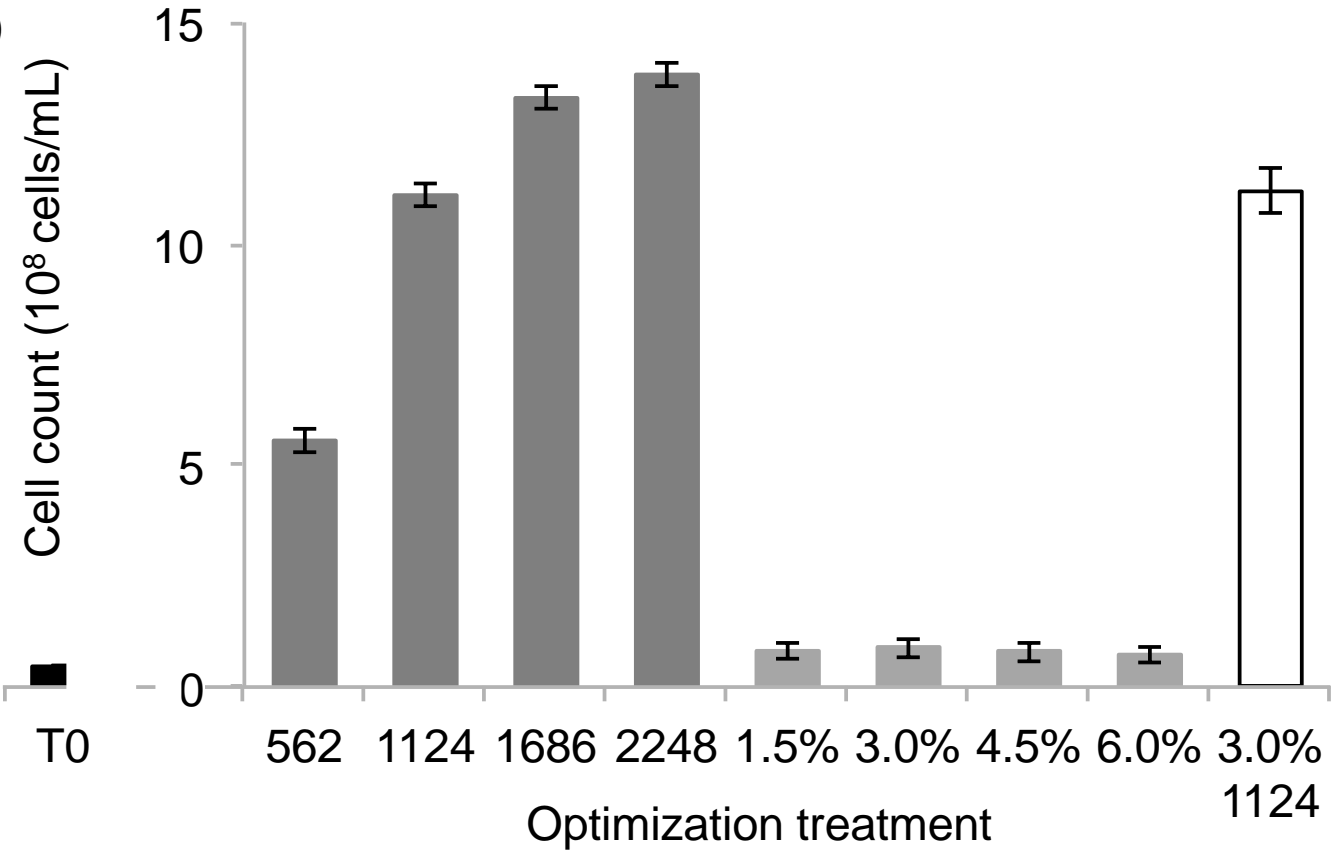

Figure 2 Bio-struvite production (a) and cell counts (b) after incubating B. antiquum for 6 days in sludge dewatering liquors supplemented with $1.5,3.0,4.5$, and $6.0 \% \mathrm{w} / \mathrm{v}$ of $\mathrm{NaCl}$, and $562,1124,1686$, and $2248 \mathrm{mg} \mathrm{COD} / \mathrm{L}$ of acetate. Error bars detail the standard error of replicate tests. 


\section{Stage 1}

B. antiquum incubated for 3 days in sludge dewatering liquors with $\mathrm{NaCl}(3 \% \mathrm{w} / \mathrm{v})$
Stage 2

B. antiquum cells from stage 1 incubated for 5 days in sludge dewatering liquors (no $\mathrm{NaCl}$ )

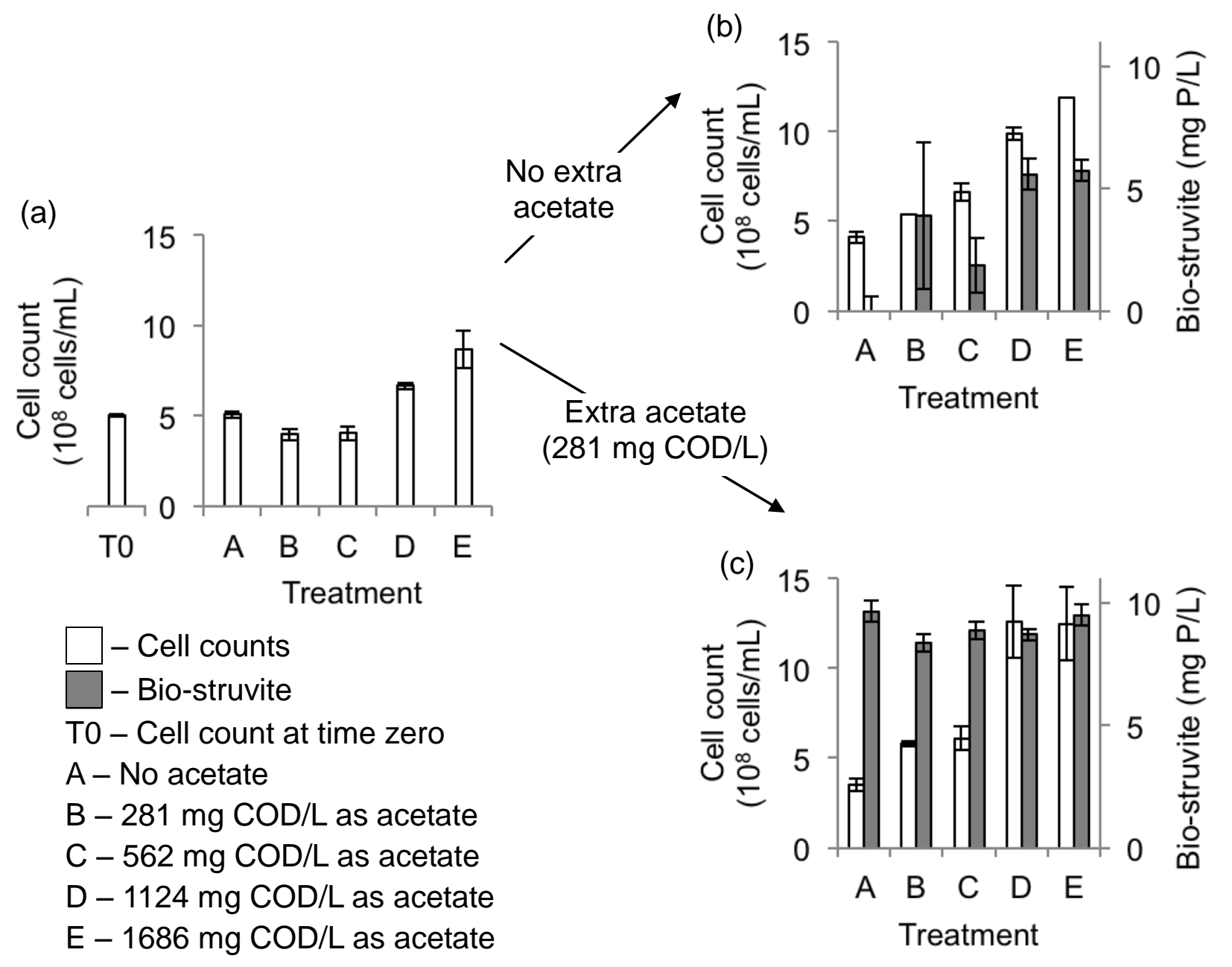

Figure 3 Maximum cell counts during incubation and bio-struvite production above control tests in the two-stage incubation experiment: (a) stage 1 cell counts when incubating $B$. antiquum in sludge dewatering liquors with $3.0 \% \mathrm{w} / \mathrm{v} \mathrm{NaCl}$ and different concentrations of acetate (Treatments A:0, B:281, C:562, D:1124, and E:1686 mg COD/L); (b) stage 2 cell counts and bio-struvite production after incubating B. antiquum cells collected from stage 1 , in sludge dewatering liquors with no $\mathrm{NaCl}$ and no acetate; and (c) stage 2 cell counts and biostruvite production after incubating $B$. antiquum cells collected from stage 1 , in sludge dewatering liquors with no $\mathrm{NaCl}$ and with $281 \mathrm{mg} \mathrm{COD} / \mathrm{L}$ of acetate. T0 details the cell count 
at time zero, after inoculating B. antiquum from starter cultures. Error bars detail the standard error of replicate tests. 


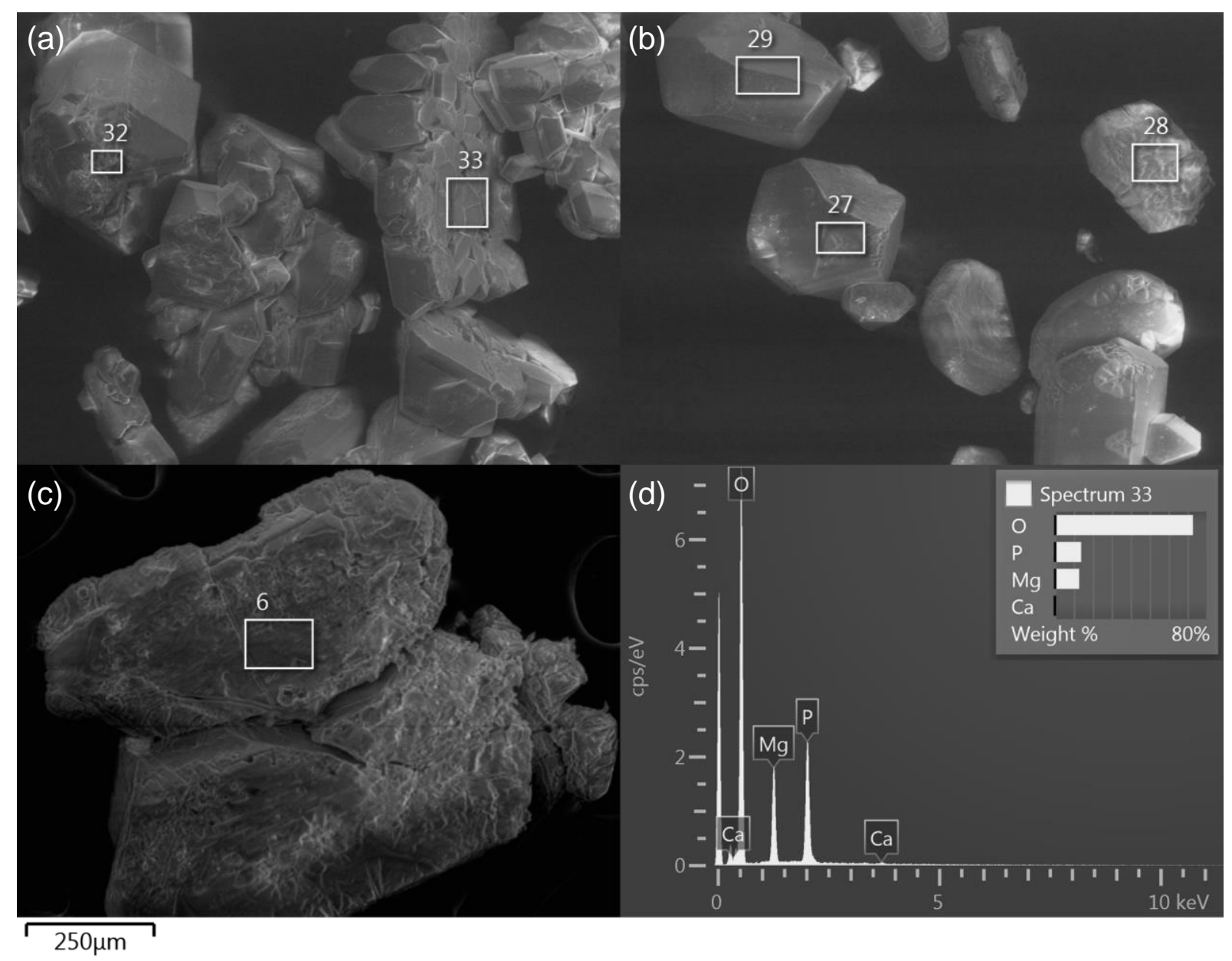

Figure 4 Electron scanning microscope photos of the bio-struvite collected after the two-stage experiment: stage 1 incubated B. antiquum for 3 days in sludge dewatering liquors with $3.0 \%$ w/v NaCl and 5 different concentrations of acetate, followed by stage 2 that incubated for 5 days $B$. antiquum cells collected from stage 1 , in sludge dewatering liquors without $\mathrm{NaCl}$, and 2 levels of acetate: (a) no acetate in stage 1, followed by $281 \mathrm{mg} \mathrm{COD} / \mathrm{L}$ of acetate in stage 2; (b) $1124 \mathrm{mg} \mathrm{COD} / \mathrm{L}$ in stage 1 , followed by $281 \mathrm{mg} \mathrm{COD} / \mathrm{L}$ of acetate in stage 2; (c) $1686 \mathrm{mg} \mathrm{COD} / \mathrm{L}$ of acetate in stage 1, followed by no acetate in stage 2. Energy-dispersive $\mathrm{X}$-ray micro-analysis spectrum of site 33 highlighted in photo (a) is characteristic struvite crystals. 
Table 1 Factors and levels tested in the screening experiment.

\begin{tabular}{|c|c|c|}
\hline Factor & Low level (-) & High level (+) \\
\hline Acetic acid & (na) & $\begin{array}{l}890 \mu \mathrm{L} / \mathrm{L} \text { from } 99.8 \% \text { Acetic acid (Acros } \\
\text { Organics). Equivalent to } 1000 \mathrm{mg} \text { COD/L }\end{array}$ \\
\hline Ammonium $\left(\mathrm{NH}_{4}-\mathrm{N}\right)$ & $510 \mathrm{mg} \mathrm{N} / \mathrm{L}$ & $839 \mathrm{mg} \mathrm{N} / \mathrm{L}$ \\
\hline Calcium $\left(\mathrm{Ca}^{2+}\right)$ & (na) & $\begin{array}{c}340 \mathrm{mg} / \mathrm{L} \text { from } 99 \% \text { anhydrous } \mathrm{CaSO}_{4} \\
\text { (Acros Organics). Increased } 100 \mathrm{mg} \mathrm{Ca}^{2+} / \mathrm{L}\end{array}$ \\
\hline Magnesium $\left(\mathrm{Mg}^{2+}\right)$ & $66 \mathrm{mg} / \mathrm{L}$ & $\begin{array}{c}300 \mu \mathrm{L} / \mathrm{L} \text { from a } 365 \mathrm{mg} / \mathrm{L} \text { solution of } \\
\mathrm{MgSO}_{4} \cdot 7 \mathrm{H}_{2} \mathrm{O} \text { (Fisher BioReagents). Final } \\
\text { conc. of } 78 \mathrm{mg} / \mathrm{L}\end{array}$ \\
\hline Oleic acid & (na) & $\begin{array}{l}387 \mu \mathrm{L} / \mathrm{L} \text { from } 97 \% \text { Oleic acid (Acros } \\
\text { Organics). Equivalent to1000 mg COD/L }\end{array}$ \\
\hline Phosphate $\left(\mathrm{PO}_{4}-\mathrm{P}\right)$ & $13 \mathrm{mg} \mathrm{P} / \mathrm{L}$ & $\begin{array}{l}1000 \mu \mathrm{L} / \mathrm{L} \text { from a } 77 \mathrm{~g} \text { P/L stock solution of } \\
\mathrm{KH}_{2} \mathrm{PO}_{4} / \mathrm{K}_{2} \mathrm{HPO}_{4} \text {. Final conc. of } 90 \mathrm{mg} \mathrm{P} / \mathrm{L}\end{array}$ \\
\hline Sodium chloride $(\mathrm{NaCl})$ & (na) & $\begin{array}{c}6 \%(\mathrm{w} / \mathrm{v}) \text { from } 99.0 \% \mathrm{NaCl} \text { (Fisher } \\
\text { BioReagents) }\end{array}$ \\
\hline
\end{tabular}

na - not altered, maintaining the original concentration in the sludge dewatering liquors. 
Table 2 Plackett-Burman experimental design of the screening experiment detailing the high $(-)$ and low (+) levels of the different factors tested.

Factor

\begin{tabular}{lcccccccccccc} 
& $\mathbf{1}$ & $\mathbf{2}$ & $\mathbf{3}$ & $\mathbf{4}$ & $\mathbf{5}$ & $\mathbf{6}$ & $\mathbf{7}$ & $\mathbf{8}$ & $\mathbf{9}$ & $\mathbf{1 0}$ & $\mathbf{1 1}$ & $\mathbf{1 2}$ \\
\hline Oleic acid & - & - & - & - & - & - & + & + & + & + & + & + \\
Acetic acid & - & - & - & + & + & + & - & - & - & + & + & + \\
Ammonium $\left(\mathrm{NH}_{4}-\mathrm{N}\right)$ & + & - & + & - & + & - & - & + & - & + & + & - \\
Calcium $\left(\mathrm{Ca}^{2+}\right)$ & - & - & + & - & + & + & - & + & + & - & - & + \\
Magnesium $\left(\mathrm{Mg}^{2+}\right)$ & - & - & + & + & - & + & + & + & - & - & + & - \\
Phosphate $\left(\mathrm{PO}_{4}-\mathrm{P}\right)$ & - & + & + & - & + & - & + & - & - & - & + & + \\
Sodium chloride $(\mathrm{NaCl})$ & - & + & + & - & - & + & - & - & + & + & + & - \\
\hline
\end{tabular}

Test 
Table 3 Characteristics of the sludge dewatering liquors collected from a full scale site (average \pm standard error).

\begin{tabular}{lccccc}
\hline & $\mathbf{p H}$ & $\begin{array}{c}\mathbf{C O D} \\
(\mathrm{mg} / \mathrm{L})\end{array}$ & $\begin{array}{c}\mathbf{N H}_{4}-\mathbf{N} \\
(\mathrm{mg} \mathrm{N} / \mathrm{L})\end{array}$ & $\begin{array}{c}\mathbf{P O}_{4}-\mathbf{P} \\
(\mathrm{mg} \mathrm{P} / \mathrm{L})\end{array}$ & $\begin{array}{c}\mathbf{M g}^{2+} \\
(\mathrm{mg} / \mathrm{L})\end{array}$ \\
\hline Screening experiment & $8.1 \pm 0.1$ & $440 \pm 6$ & $839 \pm 1$ & $14 \pm 1$ & $66 \pm 2$ \\
PSA experiment & $8.0 \pm 0.1$ & $482 \pm 1$ & $941 \pm 4$ & $32 \pm 1$ & n.d. \\
CCD experiment & $8.0 \pm 0.1$ & $479 \pm 1$ & $866 \pm 10$ & $38 \pm 1$ & $33 \pm 2$ \\
Salt/Acetate experiment & $7.8 \pm 0.1$ & $458 \pm 1$ & n.d. & $40 \pm 1$ & $46 \pm 2$ \\
Bio-struvite production experiment & $7.8 \pm 0.1$ & $418 \pm 4$ & n.d. & $41 \pm 1$ & $74 \pm 2$ \\
\hline
\end{tabular}

PSA, path of steepest ascent method

$\mathrm{CCD}$, central composite experimental design

n.d., not determined. 
Table 4 Maximum observed growth rate of $B$. antiquum for each test of the screening experiment.

\section{Test}

\begin{tabular}{ccccccccccccc} 
& $\mathbf{1}$ & $\mathbf{2}$ & $\mathbf{3}$ & $\mathbf{4}$ & $\mathbf{5}$ & $\mathbf{6}$ & $\mathbf{7}$ & $\mathbf{8}$ & $\mathbf{9}$ & $\mathbf{1 0}$ & $\mathbf{1 1}$ & $\mathbf{1 2}$ \\
\hline $\begin{array}{c}\text { Growth rate } \\
(\mu, 1 / \mathrm{d})\end{array}$ & 0.93 & 0.61 & 0.74 & 1.36 & 0.99 & 1.11 & 0.99 & 1.04 & 0.50 & 3.32 & 3.44 & 1.34 \\
\hline
\end{tabular}


Table 5 Multiple regression analysis of the screening experiment towards the response variable growth rate.

\begin{tabular}{|c|c|c|}
\hline Parameter & $\begin{array}{l}\text { Contribution to growth rate } \\
\qquad(1 / \mathrm{d})\end{array}$ & $\begin{array}{c}p \text {-value } \\
(\%)\end{array}$ \\
\hline Oleic acid & 0.41 & 0.04 \\
\hline Acetic acid & 0.56 & 0.01 \\
\hline Calcium & -0.41 & 0.04 \\
\hline Sodium chloride & 0.26 & 0.25 \\
\hline Phosphate & -0.01 & 75.85 \\
\hline Ammonium & 0.38 & 0.06 \\
\hline Magnesium & 0.08 & 9.55 \\
\hline Model constant ${ }^{\mathrm{a}}$ & 1.36 & - \\
\hline
\end{tabular}

${ }^{\mathrm{a}}$ Parameter-independent component of the regression fitted model. 
Table 6 Maximum observed growth rate of $B$. antiquum for each test on the path of steepest ascent of the linear model identified on the screening experiment. Each step adds $1.5 \%(\mathrm{w} / \mathrm{v})$ of $\mathrm{NaCl}$ and $562 \mathrm{mg} \mathrm{COD} / \mathrm{L}$ as acetate.

\section{Test}

\begin{tabular}{cccccccccccc} 
& $\mathbf{0}$ & $\mathbf{1}$ & $\mathbf{2}$ & $\mathbf{3}$ & $\mathbf{4}$ & $\mathbf{5}$ & $\mathbf{6}$ & $\mathbf{7}$ & $\mathbf{8}$ & $\mathbf{9}$ & $\mathbf{1 0}$ \\
\hline $\begin{array}{c}\text { Growth rate } \\
(\mu, 1 / \mathrm{d})\end{array}$ & $1.21 \pm 0.25^{\mathrm{a}}$ & 2.75 & 3.32 & 2.87 & 2.39 & 2.73 & 2.09 & 1.61 & 1.23 & 1.21 & 0.80
\end{tabular}

${ }^{\mathrm{a}}$ standard error of replicate tests. 